\title{
Teasing Out Striptease
}

\author{
Linda Melnychuk
}

\section{Rusant avec le strip-tease}

La féministe qui recherche la solidarité entre femmes se trouve confondue par la strip-teaseuse. Est-ce qu'elle est soumise à l'ordre symbolique patriarcal ou est-ce qu'elle resiste en subvertissant les codes qui la nomment femme publique, un 'spectacle.' Parce quele strip-teaseuse $n^{\prime}$ a pas été reconnu comme pratique signifiante, le corps de la striptease est un lieu virtuel de resistance. Mais les 'plaisirs' de ce corps sont ambigus. Et le spectacle est dominé par le regard voyeur et fetichiste du spectateur masculin. Est-ce qu'il y a un regard féminin autre? Ce texte s'interroge sur cette problématique quand l'approche objective et fetichiste du sujet de l'énonciation se confond avec l'objet du regard, parce qu'elles savent toutes les deux ce que c'est d'être regardé.

\section{Why Striptease?}

Thinking through the sex industry necessitates unpuzzling a mesh of confused and entangled power relations. It is easy to lose oneself in contradiction when the need to effectively attack the exploitative conditions that surround and constitute the sex industry is coupled with a desire to redeem and elevate sex trade workers as strong and powerful women. To try to ground oneself in these conflicting and ambiguous positions of power and vulnerability is unnerving - especially when formulating a feminist perspective on the sex industry and its workers. As a feminist, casting my lot with women, I see sex trade workers as survivors of patriarchal structures and sexist attitudes just like the rest of us. However, the exploitative conditions in which sex trade workers work and live, compel me to redeem and elevate them as superwomen. Using the term 'superwomen' to describe the sex worker may seem anomalous; the 'society-deemed-superwoman' with a successful career and family does not seem to share much in common with the sex worker. But the separation of sex trade workers 


\section{Teasing Out Striptease · 61}

from their actual work too often occurs in analyses of the sex trade and this approach often distorts the reality of the industry and alienates the sex workers from the very experiences that they face. ${ }^{1}$ Considering this, a thoroughly feminist cultural critique of any sex trade should be grounded in the experience of the worker herself.

Thank you.

Also, considering the complexity of the sex industry, the end result of a critique should not be a total condemnation nor a total redemption of these women and their work. Rather, a terrain of critical discussion. should be laid down for adequate analysis of the sex worker while creating a space for feelings of solidarity with her and her colleagues.

Colleagues? What are you trying to prove? I thought I asked you not to analyze me.

Many different professions, including striptease, comprise the sex industry. However, striptease occupies a unique position: while being a legitimized form of 'sex entertainment' it is assessed with more cultural pessimism and condescension than most other forms of sexually explicit representation. To unpack the reasons for this condescension, striptease itself must be deconstructed. In doing so, one uncovers a combination that is otherwise absent in the sex industrythe integration of sexuality and dance. This combination is significant because both sexuality and dance share the body as their instrument. ${ }^{2}$ By involving the undeniable presence of the body, and by emphasizing its corporeality and materiality, both sexuality and dance are captivating, mesmerizing methods of creating meaning. Striptease, by combining these two forces that involve and envelope the body, has the subversive potential to express the semiotic, non-linguistic, nonsymbolic meanings of our psyches. This juxtaposition of sexuality and dance can interrupt rather than reinforce the stereotypes ordinarily mapped onto female anatomy and, further, it can create the possibility of expressing female experience and especially female desire.

Yes, my body speaks - but not with words. You don't hear it but you know it.

However, striptease's potential for meaningful expression provokes a paradox: if, by its constitutive elements, the striptease can powerfully resist cultural ideology, why is it so pervasive and legitimated? 
If it is so subversive a phenomenon one wonders why there have not been national debates on abolishing the striptease, especially when most other forms of sexually explicit representation have been scrutinized and proscribed by national legislative bodies. The question, posed in another way, is whether, by combining sexuality and dance, striptease is a subversive form of cultural resistance or simply inscribed throughout with dominant ideology.

\section{The Patriarchal Intervention}

In a patriarchal order, formal, institutionalized controls and informal, cultural myths are constructed to ensure that the forces of sexuality and dance do not become too subversive. ${ }^{3}$ The quintessential example of formalized and institutionalized control over dance is the ballerina. Much of the language of classical ballet has been appropriated by the patriarchal order, making it a celebration of patriarchy ${ }^{4}$ both on and off the stage. As a synthetic construct set in an idealized world, the ballerina is an icon of femininity. ${ }^{5}$ Although her movements seem effortless, in reality they are dictated by highly disciplined and rigorous training. While the ballerina's body appears to be passively on display, it is really the result of a long production process which has determined its contours. Thus, in ballet, the body has been transformed: 'nature has become culture. ${ }^{6}$ As the final result of this controlling and formative process, the body of the ballerina signifies her initiation into the symbolic patriarchal order. ${ }^{7}$ George Ballanchine reiterated this by stating that the choreographic process was an activity of the male mind ordering and transforming 'raw nature' as incarnated in the body of a woman. ${ }^{8}$ Thus, the ballerina, produced by the male mind through choreography and guided by the male hand on stage, is a perfect participant in the patriarchal order. She is completely formalized and institutionalized: the resisting force of her body has been successfully appropriated and transformed.

Well, if the ballet is a kind of ceremony for patriarchy where do I fit into all of this?

In striptease, the resistant power of female sexuality is subverted by patriarchy. For women, sexuality is central. It revolves around our bodies which, by our own cycles, we are drawn into and made aware of every month. For women a certain subjectivity would be born out of a recognition and awareness of the undeniable presence of our 
flesh. However, this subjectivity that comes from our recognition of ourselves as pluralistic and undeniably sexual be-ings is dangerous for patriarchy. In a patriarchal society, to desexualize the female body is to affirm its non-existence. ${ }^{9}$ Therefore, patriarchy situates woman as lack, non-male, non-one: our sexuality is conceptualized within masculine parameters (the clitoris being understood as the 'little penis') and we are given no opportunity to define our own separate sexual identity. ${ }^{10}$ Therefore, by denying our plurality, all that has to occur is a manipulation of the idea of Woman. The most effective of these manipulations as a societal control of female sexuality has been the myth of the fallen woman. It is too terrifying to the patriarchal order for women to embody independent, active, sexual identities so the myth paints sexually expressive women as sorry victims who have fallen from grace and who are making spectacles of themselves. Because the myth of the fallen woman only applies to females, it follows that to be a spectacle is only a female danger. Men who express themselves sexually only expose themselves; women who do the same lose their boundaries. ${ }^{11}$ It is essential to see that the myth of the fallen woman is still a viable concept today. The myth's pervasiveness is illustrated in the open season on women who dress and behave in an overtly sexual manner and by the way strippers are easily passed off as misguided victims. Thus, from the examples of the ballerina and the myth of the fallen woman, it is not difficult to see how well patriarchy can control female sexuality and dance. These two forces that were previously determined to be powerfully subversive because of their potential for creating meanings that interrupt and subvert dominant ideologies - instead become the mediums of colonization.

\section{Redeeming the Stripper}

Wait a minute! This fallen woman stuff is scary. You call yourself a feminist and I am not sure what that means but I think it has something to do with being on my side - at least that is what you said in the beginning of all this.

Patriarchal myths regarding 'fallen women' do not embody the stripper. It would be contradictory for feminists to pose all strippers as helpless victims for that would reinforce the control that patriarchal myths have had over people's perceptions of these women and 
their work. It would also result in a denial of each stripper's personal history, a rejection of the diversity between strippers and an imposition of a monolithic, generalized description of each stripper's situation. As a feminist, one must be able to excavate the experience of women (as variously defined, identified and subject to multiple determinations) from patriarchy's symbolic and cultural constructs of proper femininity and woman-ness, in order to come to a dynamic model of social subjectivity of these women. ${ }^{12}$

I am really glad you are recognizing me in all of this but where are you going with it? You say I am working in a strictly defined patriarchal order, maybe that is true but your talk of models does not sound liberating. You really don't know what to do with me, or women like me. I really don't fit into your feminist theories very well. do I? I can't say that that bothers me!

In order to locate this social subjectivity there have been some efforts to reject the condescension that is misapplied to strippers in order to redirect it towards the environment in which they work. Feminists have been committing serious thought to the sex trade and developing arguments that locate stripping as an empowering form of cultural resistance. Feminists who pose these arguments refuse to pass off strippers as victims of false consciousness and would rather see them as free agents of sexual expression. In this view, stripping is a recognized and validated cultural commentary like established art forms such as painting, acting and opera. Although these cultural forms have the capacity to critique rather than reiterate dominant cultural ideology, the institutions and traditions that tightly control them ensure, as in ballet, that they are 'safe' for patriarchy to accept, validate and celebrate. Thus, while these cultural forms could resist dominant ideologies, they are not subversive because they exist as artefacts of and signifying practices within a patriarchal order. However, the practice of stripping itself is not subject to patriarchal control. The body, being the stripper's unwritten page or unpainted canvas, has never been a recognized textual apparatus in our culture. Stripping has been relegated to the regions of an unthinking body and has thus been seen as a practice that does not generate its own meanings. ${ }^{13}$ Dance can be seen as thoughtful action and movement of an embodied mind, however 'when it is not regarded as a signifying practice in its own right and when it is assigned a minor role in a 


\section{Teasing Out Striptease · 65}

cultural economy this distinctive capacity remains denied.' ${ }^{14}$ Thus, once the stripper's body is recognized as the unpainted canvas and unearthed from the shrouds of encoded messages under which it lies, stripping must reclaim its rightful position in culture, and become a subversive cultural commentary free from the patriarchal controls that govern 'high art'.

Unearthed? I am here, in front of you, naked, nothing on my body. Those messages are your codes, produced by you, the spectator - my body is clean. I think you are losing me in all of this. You are not listening to me.

Because the stripper is not governed by patriarchy and because her work is not institutionalized, she can free herself from hierarchies and genders. In other words, she has more authorial rights over her body and her performance text and, although she is subject to a certain male gaze, she is not under the male hand. In this way, the stripper's body can be seen as a particularized, living structure that continues to adapt and open itself to new meanings ${ }^{15}$ - maintaining its powerfully resistant force. Therefore, stripping can be seen as a reclamation of the female body and a celebration of its corporeality through dance.

Okay, but I want to know who is doing the reclaiming and celebrating of my body-you or me?

It is your reclamation and your celebration but vicariously I can also take part. You see, by celebrating their bodies, strippers are also celebrating their sexuality. They are artists who are revolting against the idea that their sexuality is shameful; they are interrupting the ideology that affirms female sexuality is wrong and dirty. ${ }^{16}$ Thus stripping can be read as a dance where women throw the construction of female sexuality back in the face of patriarchy. In this repsect, as a woman, I will benefit from their work.

\section{Problems}

\section{Why are you hesitating?}

The hesitancy revolves around my inability to understand the pleasures that strippers experience. If stripping was a reclamation of the body and of female sexuality for all women, I would not experience such disturbing feelings in stripjoints. Upon entry into the stripjoint 
I am immediately reduced to a vagina. This experience is one I cannot deny and at this point I feel it is the only one I have authority to speak about.

\section{I am glad you finally realize that.}

I just cannot understand the stripper's pleasures - they are so different from my own - and elaborating theories about pleasure does not always provide answers. Psychoanalysis tells us that when a girl is very young she is forced to turn away from the illusory unity with her mother in the pre-linguistic realm and has to enter the symbolic which revolves around subject and object. ${ }^{17}$ She is assigned to the place of object and is thus the recipient of male desire. Thus, the stripper's pleasure is constructed around her own objectification - an analysis that locates her as a woman who is revelling in her own colonization. This seems to prescribe an eternally submissive position for the stripper - a conclusion too simplistic and too disturbing.

Why are you so upset when you come into the joint?

As feminist film theory interrogated the classic cinematic apparatus and unmasked how the representation of woman as spectacle was an inherent element in the codes of cinema, perhaps the discourse of feminist film criticism can be adopted to interrupt other apparatuses that, like the stripjoint, reinforce that same representation. ${ }^{18}$ I feel the disturbing dynamic of the stripjoint is caused by a masculine positioning of the stripper's spectator. It is this positioning that problematizes my belief that strippers are celebrators and reclaimers and it is the gaze that reduces me to a vagina when I enter the joint. The voyeurism of this gaze eroticizes and objectifies the stripper's body, interrupting the subversiveness of her performance text. Her actions might be her own, but a reclamation and celebration of a woman's independent sexual identity cannot be seen with a voyeuristic and fetishistic gaze. Given that stripping occurs in a context where these processes of spectatorship are undeniably present, it is difficult to maintain the belief of stripping as celebratory without some hesitancy.

But what if I wasn't dancing for males? What if I was in front of a whole bunch of women? For that matter, what if they were lesbians or feminists or lesbian feminists? 


\section{Teasing Out Striptease $\cdot 67$}

You would then be the object of the female gaze. However, it is debatable whether or not the dynamics differ. It has been formulated that, although the gaze is not necessarily male, to own and activate it, given our language and the structure of our unconscious, is to be in the 'masculine' position. ${ }^{19}$ Also, when we talk about spectatorship, we are talking about an image or a representation that is being seen. Many feminists argue that you can not simply change the encoded meanings inherent in the messages of stripping by putting the stripper in a feminist or a lesbian context. ${ }^{20}$

But if men have this destructive gaze that women don't, stripping for women might be better.

Perhaps, however the terms female spectatorship and male spectatorship are not necessarily coincident with women and men. Rather, 'women spectators oscillate or alternate between masculine and feminine positions ... and men are capable of this alternation as well. ${ }^{\prime 21}$

So, how do you know where a spectator is positioned?

It is usually the case that men and women enter spectatorship as social subjects who have been compelled to align themselves as spectators in a way that reflects their social/sexual difference. ${ }^{22}$ Therefore, it is most common for women and men to adopt the feminine and masculine gaze respectively - this is what is in line with their socialization and psychical positioning.

Can you please tell me what position you are occupying in this discussion?

I do not know, my position is very unclear and quite tenuous. I am adopting very privileged and abstract discourse to try to think you through, yet this discussion is revolving around the issues of female sexuality and dance - both of which have been integral to my own existence. Thus, I am the objective critic, yet I am also the phenomenon being critiqued. My route to creating a critical analysis of striptease has led me to an impasse. In one respect, I cannot be the critic without assuming the dominant position and, because I am so experientially removed from your work, this dominance has led me to falsely construct you. Therefore, I am just as culpable as patriarchy is for creating a story about you that mystifies and distorts your own. Secondly, although I began this discussion with the tone of an 
objective critic my position of dominance collapses when I begin to realize how much of our dialogue revolves around my own sexuality, dance, looked-at-ness.

You tried to understand my experience.

Grounding my analysis in your experience was too difficult - I am too far removed from it. However, I also cannot be objective for there is too much of me, as a woman, in this conversation.

You can't get close enough to me yet you can't stay far enough away. To solve this dilemma you looked down into my world with the desire to understand it and, probably, to 'fix' it.

I only wanted to know you.

You don't.

How can I?

By working through my story and hearing myvoice ... before you begin to write.

\section{Notes}

1. Laura Bell, Good Girls/Bad Girls: Sex Trade Workers and Feminists Speak Face to Face (Toronto: Women's Press, 1987).

2. Judith Lynn Hanna, Dance, Sex and Gender: Signs of Identity, Dominance, Defiance and Desire (Chicago and London: The University of Chicago Press, 1988), xiii.

3. Elizabeth Dempster, 'Women Writing the Body, Grafts: Feminist Cultural Criticism, ed. Susan Sheridan (London and New York: Verso, 1988), 38.

4. Ibid., 39.

5. Ibid., 41.

6. Annette Kuhn, 'The Body and Cinema: Some Problems for Feminism,' Grafts: Feminist Cultural Criticism, ed. Susan Sheridan (London and New York: Verso, 1988), 17.

7. Dempster, 41.

8. Ibid., 42.

9. Mary Anne Doane, The Desire to Desire: The Woman's Film of the 1940's (Bloomington and Indianapolis: Indiana University Press, 1987), 19.

10. Ibid., 15.

11. Mary Russo, 'Female Grotesques: Carnival and Theory,' Feminist Studies,/Critical Studies ed. Teresa de Lauretis (Bloomington: Indiana University Press, 1986), 213.

12. Ibid., 214. 


\section{Teasing Out Striptease - 69}

13. Dempster, 38 .

14. Ibid., 39.

15. Ibid., 48.

16. Margaret Dragu and A.S.A. Harrison, Revelations: Essays on Striptease and Sexuality (London, Ontario: Nightwood Editions, 1988), 53.

17. Anne Kaplan, Women and Film: Both Sides of the Camera (New York: Routledge, 1988), 26.

18. Teresa de Lauretis, Alice Doesn't: Feminism, Semiotics, Cinema (Bloomington: Indiana University Press, 1984), 4.

19. Kaplan, 29.

20. Mary Bos and Jill Pack, 'Porn, Law, Politics,' Looking On: Images of Femininity in the Visual Arts and The Media (New York and London: Pandora Press (Routledge and Kegan Paul), 1987), 187.

21. Doane, 8.

22. Ibid. 